\title{
Investor Sentiment, Information Disclosure and Corporate Investment Behavior
}

\author{
Zhang Yanyu, Xu Qiang \\ College of Economics and Manegement \\ Nanjing University of Aeronautics and Astronautics, Nanjing 210016, China \\ Email: carina1102@126.com
}

\begin{abstract}
Behavioral Corporate Finance believes that disclosure of corporate information, not only affects the corporate value but also affects the expected growth of the enterprise market investors. Investors would give the lower level of disclosure of the stock a higher level of risk. This paper selected the Shenzhen Stock Exchange company data during 2006-2014, and introducted the cross-term of information disclosure and investor sentiment. It analyzed the relationship between information disclosure and cater channels. It was found that managers of listed companies tend to cater to a positive correlation on investor sentiment, and the higher the level of disclosure for companies, a stronger tendency of catering to the market sentiment managers have.
\end{abstract}

Keywords: investor sentiment, information disclosure, cater channels, corporate investment behavior

\section{Introduction}

In the traditional theory of corporate finance, investment decision-making behavior is based on the theory of efficient markets, rational investors, perfectly competitive market, full disclosure of information and other assumptions that determine the market price signals can reflect value of the company, company managers and investors in the market judge these decisions based on market signals. However, the reality is not the case. With the improvement and development of China's market economy system, the quality of information disclosure of listed companies are payed people's attention. It reflects not only the quality of listed firm's value, but also affect investors' expectations for corporate equity, thereby enabling business managers to make appropriate investment decisions.

In this paper, based on previous studies on the introduction of information disclosure quality indicators, we are trying to solve the following two questions:

(1) dose investor sentiment affect on corporate investment behavior?

(2) If sentiment affect corporate investment, the better the quality of information disclosure, is the investor sentiment on corporate investment behavior not higher?

Content moiety what this article is: The second part is a literature review; the third part is the research design; the fourth part samples, data and empirical results; The fifth part is the conclusion and study limitations. 


\section{Review}

A large number of "signs" that appear on the capital market showed that investor sentiment may play an important role in the formation of asset prices. Blanchard, Rhee and Summers (1993)[1] studied the relationship between stock "mispricing" and the company's investment decisions. They believe that these two conditions that the stock price deviation from the basic value and the duration of shareholders is to determine whether that company managers make investment decisions catering to develop the stock price. If managers based on business objectives and long-term development strategy are the company's long-term shareholder, they will judge on the basis of their investment management decisions. Based on research achievements over the years, they showed that there are two main channels for investor sentiment affecting investment behavior: equity financing and rational cater channels. Baker et.(2004 ) [2]drawed on market timing and other points of view, and pointed out the error to the pricing in the market will affect investment decisions by fluctuations in the level of equity financing, namely equity financing theory of corporate investment decisions. Polk and Sapienza (2006) [3]proposed the theory of channels catering to the business investment decision, they pointed out that on the basis of the theory investor sentiment led to "asset mispricing" directly affecting the company's investment.

\section{Empirical Design}

In this paper, when studying the relationship between investment behavior and investor sentiment, they are mainly from the perspective of the mechanism and market efficiency information. According to Baker, Ruback and Wurgler (2007) [4]theory, when investors are overly optimistic or overly pessimistic, the company will have a financial policy bullish or bearish investor sentiment and cater to that sentiment to make decisions, driving prices further up or down. Business managers will take the initiative preference in the interest of investment project that investors like, so the level of business investment will improve. Thus, we propose:

Hypothesis 1: In China's stock market, investor sentiment would have a positive impact on corporate investment behavior.

In a capitalist market, the information disclosure quality directly affects investors' rational investment and healthy development of the market. According to Barry and Brown (1984)[5], Handa and Linn (1993)[6] and other studies they have found, the company would like to increase the quality of information disclosure in order to reduce information asymmetry among investors, or they would like to reduce the stock costs for transaction to enhance stock liquidity for reducing financing costs, thereby enhancing investor sentiment positive and optimistic, so that business managers would meet investor sentiment and expand business investment. Thus, we propose:

Hypothesis 2: If investor sentiment does affect corporate investment, the better the quality of information disclosure have, the more obviously investor sentiment affect on corporate investment behavior.

\section{Sample, Data and Empirical Results 4.1 Sample and Data Sources}


This article used the quality of information disclosure indicator and the data are come from the Shenzhen Stock Exchange, and this rating is from 2006, so the paper selected corporate data in the Shenzhen Stock Exchange and the interval research was from 2006 to 2014. In the sample selection, the exclusion of part of the abnormal performance of the company was included: companies that have financial insurance and other financial data specific; companies that have PT, ST, or companies have lost data for other reasons and other long-term suspension observed up to 6 months or more companies; companies that have incomplete data. Finally we have obtained 357 listed company data and 3213 observations. All data are come from Guotai Junan Research Service database, and we use Stata software for data processing.

\subsection{Variable}

\subsubsection{Investor Sentiment}

Selecting the metrics of investor sentiment has been a difficult point in financial behavior study. This article learned from the momentum indicators that Polk and Sapienza(2006)[7] have designed, taking the existence of momentum effect timeliness into account, usually 3-12 months. And in our stock market our momentum indicator is a significant presence in the six months, and more than half of the time or more will be reversed, so we use six months of momentum indicators as proxy for investor sentiment to carry out follow-up study, that lagging a cumulative monthly rate of return of 6 months to measure investor sentiment:

$$
\text { Sent }_{i, t}=\sum_{i=7}^{12} R_{i, t-1}
$$

Here $i$ is the month, trepresent the year, $R$ represent the monthly cash dividend of stock returns.

\subsubsection{The Quality of Information Disclosure Index}

In the study of information disclosure of listed companies, previous scholars have done a lot of academic research during the past years on information disclosure measure. we found that there are four ways: first by the number of disclosure as a proxy indicators. This article is followed this approach, according to the Shenzhen Stock Exchange issued annually to measure the indicators.

In the text, the information disclosure quality indicators are made as a cross-term investor sentiment. According to the Shenzhen Stock Exchange's rating, A, B, C, D respectively use with $\mathrm{ID}=1, \mathrm{ID}=2, \mathrm{ID}=3$, ID $=4,1$ for the best quality of information disclosure, 4 for the worst of information disclosure quality.

\subsubsection{The Investment Level}

This article reference theory that Baker and Wurgler (2007)[8] proved, and measure the level of business investment with the purchase of fixed assets, intangible assets and long-term investments Net cash paid divided by total assets at the beginning.

\subsubsection{Other Variables}

Taking other variables interfering with the study results into account, we selected other variables as control variables, see Table 1 . 
Table 1: Main variable definitions

\begin{tabular}{c|c|c}
\hline Variable & Variable symbol & Definition \\
\hline investment level & Inv & Expenses of fixed assets,intangible assets and other assets / total assets at the beginning \\
\hline investor sentiment & Sent & Six months of Momentum Index \\
\hline Disclosure Index & ID & The Shenzhen Stock Exchange Rating \\
\hline Tobin's Q & Q & It is defined as the ratio of corporate market value and replacement value \\
\hline Free cash flow & CF & Net income,depreciation and amortization / total assets a year earlier book \\
\hline Assets and liabilities & Lev & Closing total liabilities / total assets of the end of the company size \\
\hline Company size & Size & Opening book natural logarithm of total assets \\
\hline Industry dummies & Industry & \\
\hline Year dummies & Year & \\
\hline
\end{tabular}

\subsection{Model}

For hypothesis 1, we refer to Polk and Sapienza(2004)[9] and Baker and Stein(2004)[10] research models to create test investor sentiment and the investment level relationship model as follows:

$$
\operatorname{Inv}_{i, t}=\beta_{1} \text { Sent }_{i, t}+\sum \text { control }+\varepsilon_{i, t}
$$

In order to test the second hypothesis that whether the different quality of information disclosure of companies will have a significant difference of catering to investor sentiment, and we have introduced a measure of cross terms of information disclosure, and the cross coefficient ${ }_{2}$ represents different quality of information disclosure of enterprises, and its managers would appear the difference to meet investor sentiment. The model is as follows:

$$
\mathrm{Inv}_{i, t}=\beta_{1} \operatorname{Sent}_{i, t}+\beta_{2} \text { Sent }_{i, t} \times I D_{i, t}+\sum \text { control }+\varepsilon_{i, t}
$$

\subsection{The Empirical Results}

After setting the time and industry dummies, we sample panel data analysis, and empirical results are shown in Table 2:

\begin{tabular}{ccc} 
& Model 1 & Model 2 \\
\hline Variable & Inv & Inv \\
Sent & $0.174^{* * *}(0.12)$ & $0.112^{* * *}(0.09)$ \\
Sent*ID & & $0.806^{* * *}(6.54)$ \\
Q & $-0.310^{* *}(-1.51)$ & $-0.32^{* *}(-1.6)$ \\
CF & $0.113^{* * *}(14.87)$ & $0.084^{* * *}(12.41)$ \\
Lev & $0.059^{* * *}(3.25)$ & $0.074^{* * *}(4.10)$ \\
Size & $0.027^{* * *}(2.89)$ & $0.285^{* * *}(1.33)$ \\
Industry & control & control \\
Year & control & control \\
Adj- $\mathrm{R}^{2}$ & 0.1205 & 0.0534 \\
F & 56.784 & 65.41 \\
\hline
\end{tabular}

Notings:()represent $t$ value of the regression coefficient, ${ }^{* * *}, * *, *$ represent significance level of $1 \%, 5 \%, 10 \%$

The regression results of model 1 can be seen that, after controlling for free cash and other control variables, the regression coefficient of investor sentiment variable is 
0.174 and it is significantly positive, indicating that in our country, the impact investor sentiment on corporate investment behavior exists, and the trends for managers of listed companies catering to investor sentiment are positively correlated. Model 2 adds packet dummies information disclosure index, which crossing coefficient and investor sentiment was also significantly positive, reaching 0.806 . It proves the second hypothesis that the higher the level of disclosure for companies, the lower the expected return on the future risk investors have, so managers will have a stronger tendency to cater to the market sentiment.

\section{Conclusions and Research Limitations}

During the study, with the limited space and the ability to author, many problems will be waited to solved, and we need further discussion. It also provides a reference for future empirical research. First, selecting the quality of information disclosure and investor sentiment index has always been a kind of important and difficult research. Here we learned from measure past experience research of other scholars by reference. Though it is with a certain rationality, it is not a long-term certainly one, and it is also one-sided. Accordingly, in follow-up studies we should think about comprehensive measurement indicators to ensure accuracy. Then, although Chinese capitalist market is developed, the development is not perfect, which has a certain degree of particularity. So it brings some limitations to this study.

\section{References}

[1]Blanchard, Rhee and L.Summers,1993, The stock market profit and investment, Quarterly Journal of Economics 108,5-136.

[2]Baker M and J.Stein,2004, Market Liquidity as a Sentiment Indicater, Journal of Financial Markets 7,271-299.

[3]Polk C and P. Sapienza,2006, The stock market and corporate investment: a test of catering theory, Review of Financial Studies, forth coming,34(1):234-258

[4] Baker, Ruback and Wurgler ,2007,Market timing and capital structure, Journal of Finance 57,1125-65.

[5]Barry.C.B and Brown S.J,1984, "Differential Information and the Small Firm Effect", Journal of Financial Economics,13(2):283-295.

[6]Handa P and Linn S ,1993,“Arbitrage Pricing with Estimation Risk”, Journal of Financial and Quantitative Analysis,28(1):81-100.

[7] Polk and Sapienza, 2006,Investor Sentiment and the Cross-Section of Stock Returns, The Journal of Finance 61,1645-1680.

[8] Baker and Wurgler 2007, Appearing and Disappearing Dividends: The Link to Catering Incentives, Journal of Financial Economics 73,271-88

[9] Polk and Sapienza,2004, Market Liquidity as a Sentiment Indicater, Journal of Financial Markets 7,271-299.,

[10]Baker M and J.Stein, 2004, Market Liquidity as a Sentiment Indicater, Journal of Financial Markets 7,271-299. 